\title{
HEALING IN A CULTURAL CONTEXT: THE ROLE \\ OF HEALING AS A DEFINING CHARACTER IN THE GROWTH AND POPULAR FAITH OF THE ZION CHRISTIAN CHURCH
}

\author{
James Kenokeno Mashabela \\ University of South Africa (UNISA) \\ jkenokeno@gmail.com
}

\section{ABSTRACT}

This article revisits the role healing has played in the growth of the Zion Christian Church (ZCC) as one of the fastest growing African Independent Churches (AICs) in South Africa. The article argues that the ZCC is appealing to black Africans because it addresses healing within the cultural context of an African. ${ }^{1}$ Healing within the cultural context speaks to the fundamental needs of an African. The fundamental needs of an African see healing as addressing more than just a body ailment, but the totality of a person. The paper revisits the history of healing in the ZCC, and in so doing, will be a revisit to this church's history. In revisiting this history, the discrimination that this church faced from the political authorities and from the white mission churches will also be referred to.

Keywords: Zion Christian Church (ZCC); healing; Africanisation; cultural context; African Independent Churches (AICs); baptism

\section{INTRODUCTION}

In 1977, field work research regarding healing and Holy Spirit theology within the circle of the African Independent Churches (AICs) became necessary in order to Africanise Christianity in South Africa and Africa. South African and African academics within the fields of theology and psychology came together in the study of how healing is experienced within black South Africans and on the African continent (Poewe and Hexham 1989, 1-2). Although at that time many black people were members of the

1 Disclaimer: The word African refers to the original term for black people. The word Western refers to the original term for white people.

\section{UNISA $\cong$}


South African mission churches/mainline churches, African Pentecostal churches and the AICs had more members, and it was clear that the largest independent church in 1984 was the Zion Christian Church (ZCC) (Poewe and Hexham 1989, 7). South African church history events reveal that the ZCC, as the popular faith character and one of the AICs' movements, has seriously taken into consideration the needs of African healing and cultural context in South Africa. Africans have always believed in healing; not just healing, but an African understanding of healing, which is mostly associated with boloyi (witchcraft). The ZCC has applied the principle of healing within the African cultural context. Historically, the ZCC was founded in 1924 by Engenas Barnabas Lekganyane, who was born at Mamabolo in the then Pietersburg in 1885 (Lukhaimane 1991, 227228). As oral history engagement in this article is central, an approach to interview ZCC members was considered. Initially eight ZCC members agreed to be interviewed, however, eventually only three agreed to be interviewed without their names being disclosed and five members withdrew. In ZCC spirituality, there is sensitive information that must not be disclosed. This was treated with respect as an ethical necessity.

\section{THE RISE AND HISTORY OF THE ZCC}

In 1910, Engenas Lekganyane received his God's divine influence to become a healing prophet. After this spiritual journey, he could not confront the leadership of his Scottish Free Church to declare his experience with God in an African landscape. He later on left his original birth place of Mamabolo, situated in the now Limpopo Province, to an area known as the Reef/Boksburg. There he joined the Zion Apostolic Church of South Africa, established by Rev. Elias Mahlangu who baptised him and received his healing in 1912 (Moripe 1996, 18). Lekganyane, a gifted preacher who performed miracles, preached African sermons and related them to the Bible. This was a threat to the Western doctrine of the Zion Apostolic Church, but relevant to Africans. In the Mamabolo area, he pioneered the Zion Apostolic Church through his African preaching and healing gift and many people became his followers. He was ordained and then formed his own Zion Christian Church in 1916. This was due to his different approach in administration and management of the church, from what he had used when working with Mahlangu (Häselbarth 1966, 1; Moripe 1996, 19). The ZCC formation was also a strong challenge against the white missionary and government dominant policies which undermined and destroyed African spirituality, culture and heritage. Western culture and Christianity were problematic to Lekganyane and his African counterparts. The ZCC was an encounter against the imposed Western culture and white church practice to the African way of life and values. The ZCC became an African-pioneered, faith-based and African-centred church as opposed to the Western traditional and white church; radically so, as Zandisiwe Radebe states:

The ZCC, among many other religious movements, has throughout colonial and apartheid times haltingly conducted its cross-border activities. Up to the present day, this transnational movement 
manifests during the annual Easter festival which takes place in the province of Limpopo (within the national boundaries of the state of South Africa). (Radebe 2008, 51)

The ZCC remains one of the greatest AICs that appeals to the African way of healing the sick and that upholds sermons that are African-centred. The ZCC as an African church embraces a reality of African people that being an African, you could not separate the spiritual life and the material gifts of God. This church is not only spiritually centred, but has also emerged as an AIC which is politically committed and at the forefront of the struggle for liberation and transformation of the AICs (Ngada 2001, 51). The ZCC is viewed as the AIC that overcame the perceived inferior status of African churches and it has emerged as the leading spiritual church that is African-centred. Lekganyane's vision was to grow the ZCC beyond the South African borders; hence his church was not named "Zion Christian Church in South Africa" although it was established in the South African landscape (Moripe 1996, 20). This church attracts the poor and uneducated, the oppressed and the marginalised Africans, and serves as a refuge for Africans. It has critically developed a radical reconstruction to accommodate these ignored situations of the black people. The ZCC represents what Maimela stated: "The greatest attraction of these churches lies in their open invitation to the Africans to bring their fears and anxieties about witches, sorcerers, bad luck, poverty, illness and all kinds of misfortune to the church leadership" $(1985,71)$. This means that the ZCC has become the Africancentred church that certainly answers the African's ignored questions and spiritual realities which the mainline churches, Pentecostal and charismatic churches never attempted to answer because of their Western worldview approach of Christianity. The ZCC is the largest amongst the AICs that has faithfully remained within the African structural communities as defined by Africanisation (Moripe 1996, 183). The ZCC is committed to Africanisation, which takes seriously the African spiritual life at the very point of its church history. It takes Africanisation to align itself with the Word of God as the good news to Africans. Moripe observed:

African Christian Theology is emerging from the African hermeneutic because the questions it addresses are African and the answers have to speak to the African situation in the light of the Word of God. Thus speaking to the soul of an African. The African is first and foremost a human being and then a believer. In fact, African Christian Theology is a reflection of what the Biblical God is doing to enhance African survival through the agency of people who are informed by Scripture and traditional concepts of God who is revealed to us through the faith and life of Jesus Christ (Moripe 1996, 169).

It is only from this creative method of African theology that Africanisation has clearly developed to fulfil the African Renaissance. It is the task of African theology, African women's theology and Black theology to ensure that Africanisation is indeed perceived by the Africans as opposed to the Western theology. 


\section{THE MESSIANIC ROLE OF ENGENAS AND THE HEALING IN BAPTISM}

"Engenas was found to be rich, real and relevant in his teachings. What he said at annual conferences would form the theme for preaching in the congregations" [own emphasis] (Lukhaimane 1991, 232). His followers called him "powerful doctor or they called him chief, prophet and even Messiah, Redeemer" (Häselbarth 1966, 1). Engenas's followers used these names because of the healings he performed for his people and also for his preaching. Lukhaimane argues that Engenas could not be referred to as Jesus Christ or the Messiah/Redeemer just because his followers chose to refer to him in that way (Lukhaimane 1991, 238). What was claimed about Engenas was that he accepted Jesus Christ as the Son of God, the Bible as the word of God, and ordained his ministers to fulfil his called ministry within the African society. It is argued that Engenas did not like to be called such names; instead he preferred to be called "bishop". In an interview, a member said: "As ZCC members we prayed in Engenas's name and Jesus' presence was respected, but not central to our faith" (Mashabela 2016). It could be critically important that the ZCC members' faith in the church of Engenas be treated with respect and dignity for their freedom of religion, as that was how their faith was practised. Other African Christian people who were not ZCC members had criticised this faith-vision approach as evil and un-Christian. This was influenced by the trained white and African pastors with an achieved oppressive Western education. Jesus Christ was viewed as the white God, whereas Engenas appealed to ZCC members as an African church initiator. Engenas had more powers and was more highly respected than the chief (Häselbarth 1966, 7). There was a perception among ZCC members that Engenas was the Messiah to the extent that in prayer, they mentioned and prayed in the name of Engenas. Further, in baptism, the threefold immersion in water was in the name of Engenas Lekganyane, Edward Lekganyane and Barnabas Lekganyane (Mashabela 2016). Let us then look at baptism.

\section{Baptism}

Baptism in the ZCC is viewed as healing and not necessarily for the forgiveness of sins. Baptism within the ZCC is implemented without any cost, as opposed to the African mission churches and African Pentecostal churches. During a baptismal ceremony, the congregation would dance and sing with joy as new members of the congregation receive new clothing, uniforms and badges. The church would also baptise traditional healers/doctors who would hand over dices and charms (dipheko or ditaola) to the church. The church would keep them, although the church is also called kereke ya bongaka ("diviners' church"). These spiritual healers are discouraged from using dipheko since they are now ZCC members. In this church, most of the prophets are former traditional healers (Häselbarth 1966, 11). According to Allan Anderson's view: "We asked members of the ZCC (among others) why they were attracted to their church. 
The answer was often based on an appreciation of the 'African' nature and orientation of the church. ZCC members referred to the African liturgy of the church, especially the singing and dancing. Their church was especially geared to fulfil African aspirations and to meet African needs" (Anderson 2003, 107). Therefore, ZCC members have developed an African church to embrace African identity and culture and to continue with the debate of Africanisation. This invited the African mission churches and African Pentecostal churches, as well as theological higher education, to move away from spiritual, economic and political injustices caused during the apartheid epoch. Members of the congregation claimed that they joined the church because they received healing from it. The ZCC does not heal only those who have joined the church, but also those who are not members. The members' interest lies in witnessing faith healing. ZCC membership growth is done through home visits, which play an important role in the life of this church. What motivates this growth is an approach whereby in healing, the culture of the African people is taken into consideration. The members of this church would not consider that they have been assisted successfully when they visit medical doctors, diviners or traditional healers and other prophets (Anderson 2003, 107).

\section{AFRICAN HEALING IN THE WHOLENESS OF LIFE}

If the Bible was rarely used, what was then preached? The ZCC of Engenas was known as a faith-healing and a miracle-performing church and every act in the church was an act of God. Ministers would preach on how a person was healed, how a barren woman conceived, how a witch was caught and other social programs which were solved in the church [own emphasis] (Lukhaimane 1991, 232-233).

The ZCC doctrine is at the heart of prophetic and healing practices, which attract and fulfil many black people's needs. In an African context, witchcraft cannot be avoided with regard to misfortune or illness, and the ZCC offers an alternate hope with an African solution to these agonies. Members claim to be protected from evil spells (witchcraft), which is not the case in African Pentecostal churches and mainline churches. The attraction of the healing service in the ZCC provides a space for dancing and singing, which forms part of the most significant requirement for healing the sick and answering prayers. One of the terms used for dancing is mpoo (this is dancing by a group of men, all wearing church attire) (Mashabela 2016). These are qualities required in an African context to fulfil the spirituality of Africanisation. Africanisation can be seen as the divine call of Africans to be allowed to live their African lifestyle. In actual fact, even in Pentecostal and mainline churches, dancing and singing is a daily reality. However, the Western missionaries taught these churches not to dance during worship, which is totally un-African.

Within the ZCC, prophets play the important role of healing church members and even non-church members. They are gifted with divine powers and receive the message from God in order to address the concerns of the spiritually challenged African people. 
They are entrusted with, and responsible for a key office to pray for the healing of its members. Anderson states: "The prophet is somebody who helps people when they are sick, was one typical response. Their healing practices are expected to be effective and to actually bring healing to the patients" (Anderson 1999, 298). Africans believe that prophets are entrusted with the gift of healing the sick. This is derived from the African understanding of a traditional diviner or healer who uses ditaola that she or he has inherited from her or his proctor ancestors (badimo bagolo). The healing power originates from God, and even a notion of the prophet reveals the same in the Bible. The prophets' duties are to advise the sick on what their ancestors expect to be done in order to be healed (Mashabela 2016).

Members bring ditaelo (instructions) in the form of holy water, holy papers and coffee, and also consult the prophets (Häselbarth 1966, 5). Anderson states: "The ZCC now also uses special tea and coffee made for healing purposes, labelled in Sesotho, tee ya bophelo" (tea of life) (Anderson 1999, 306). Anderson's view that tea and coffee are new practices differs from the conducted interviews. During the interviews, it was confirmed that tea and coffee are old forms of healing and have been used since the church's inception (Mashabela 2016). This African approach of healing is the African spiritual worldview as opposed to the Western psychologists and anthropologists who think of it as an invented memory by the Africans. In the African spirituality worldview, it is critically important to use coffee and tea as they are not invented memories but practically and historically lived memories within the ZCC spirituality. Historical research shows that white psychologists and anthropologists' work is mainly to deny and critique the AICs, including the ZCC, on how they practise their spirituality. These white professionals ignore the genuine African spirituality, spiritual ideas and voices of the Africans. However, the well-being of the Africans' spirituality and reality cannot be ignored as being part of an Africa worldview. White psychologists and anthropologists will not determine and interpret the reality of the African worldview, including the theologians. Only Africans can determine and interpret their African spirituality. In the African tradition, coffee and salt are poured into church members' shoes, cars and houses for cleansing and protection (Mashabela 2016). The prophet sprinkles and pours holy water, which is then dispatched to the church members. The prophet prays over the water before using it for the healing or protection of members (Anderson 2003, 111). When the sick are given ditaelo, they cannot enter into someone's house or shopping centre; they have to take the ditaelo straight to their home. If one enters into someone's house or any place with ditaelo, this will lead to šilafalo (misfortune). The sick are instructed to buy specific products in order to be prayed for, for the purpose of ditaelo. At the interviews during this study, cold drink was mentioned as a source for healing against witchcraft and evil forces. A prophet could prescribe Fanta Orange cold drink to a church member to pour over her or his body right from the head. This is used to remove a spirit from an individual body. Again, one could be instructed to bring a particular kind of cold drink, depending on the illness, which then had to be broken on the street at an intersection (Mashabela 2016). The cold drink's container has to be a bottle, the breaking of which 
symbolises a form of confusion against dira tšaka (my enemies). An individual would face bodikela tšatši (sunset); after breaking the cold drink bottle, the individual would not turn around until they have reached home, otherwise the challenges would not be resolved or would become worse. This means that an individual will be completely healed and not be bewitched again by enemies. The concept of ditaelo is that it cannot be shared with anyone, including family members. Sharing ditaelo with anyone is a betrayal for someone's healing and common good. This is another type of healing in protest against the mainline, Pentecostal and charismatic churches that only regard their own way of Western healing as being valid and effective.

Lazarus Lebeloane and Mokhele Madise have provided an explanation for other types of water usage in their article titled, The use of different types of water in the Zion Christian Church, which identified that: "Water is perceived as a gift from the Creator. It is further understood to have life-giving and life-invigorating power if it has been blessed by either a minister of religion or a traditional healer (called inyanga or ngaka)" (Lebeloane and Madise 2006, 146). Water is mentioned in the Sepedi phrase, meetse a thapelo, meaning water of life, as the source of healing within the ZCC and used to purify members at their homes, funerals and other services (Anderson 2003, 112). Water, within the ZCC, undoubtedly has a critical role for induced vomiting in order to get rid of sickness and spiritual fears. According to Anderson: "The water is seen to represent cleansing and purification from evil, sin, sickness and ritual pollution, concepts familiar to traditional religion" (Anderson 1999, 305). Water is not only viewed as plain water, but as holy water, which is used for bathing purposes as well. ZCC members and nonmembers will be sprinkled with water before they enter into the house of the prophet or the church. This is for the purpose of cleansing and searching for evil spirits. The interviews confirmed that only prophet men are allowed to stand at the gate of the house of the prophet or church to sprinkle people and they cannot allow those who practise witchcraft at the services. Women are not allowed to attend prophecy services if they are menstruating as they are regarded as unclean. When asked how they felt when they could not attend services, they said: "... molao wa kereke o re ga raswanela go tsena tirelong" (this was the rule of the church that we could not attend the service) (Mashabela 2016). When women are denied to enter the church premises and perform their church duties in the ZCC, it means that the ZCC displays the wrath of God. This ZCC approach on women does not respect the rights and dignity of women. If the ZCC were serious about the well-being of Africans, it means that it could allow and treat women fairly to attend the church services. African women were created in the image of God, thus the ZCC is called upon to respect the rights of women. The ZCC has been challenged by women to attempt to develop an African Women's theology that understands the nearness of God to African women. The solidarity of women in Africa is that God is nonviolent but compassionate to heal and liberate them from all sources of oppression by the African church. Because menstruation is considered God's creation, women have protested against the ZCC in search of freedom to attend the church services. 
Other examples of typical African healing cultures are wires above the entrance door on church members' homes used for protection from witchcraft and against lightning strikes. Another source of healing used by the priest/prophet (in Sepedi) is kotana, a small piece of wood and sebepu, meaning a belt tied to the wood (Anderson 2003, 113). Anderson outlines these ditaelo, but does not explain how they are used. Interviewees suggested that before they use kotana to kokota (beat a person around her or his body), one would be counselled and then told what could happen next. Sebepu is twisted around an individual's body without touching her or him. These forms of ditaelo are rituals for healing and protection within ZCC circles (Mashabela 2016).

\section{WAS ZCC SEEN AS AN ANTI-CHRISTIAN MOVEMENT?}

Before and after 1960, the Pan Africanist Congress (PAC) gave a shoulder of support to the AICs, particularly as these churches were seen as African Christianity led by black people, and providing its leadership with both the African traditional religion and culture (Kretzschmar 1986, 10). The PAC supported the success of the politicised AICs' idea of being an African national church that was relevant to the African people. It was against this background that mission churches and Pentecostal churches never supported the idea of African churches' worldviews. According to Tinyiko Maluleke: "The AIC movement was seen as an 'uneducated' and, therefore, a dangerous challenge to historic missionary churches. This movement was seen as an ecclesiastical counterpart to the political 'native problem'. Interest in AICs was, therefore, neither neutral nor sympathetic" (Maluleke 2003, 179). The ZCC relations to the AICs movement was unapologetic about providing relevant spiritual and healing services to the needs of the Africans, although the mission and Pentecostal churches had applied unjust religious, political, economic and cultural behaviour towards the ZCC. This was also dictated by the apartheid government. The ZCC has continued to survive against the background of being poor, exploited and marginalised by these churches.

In 1991, Lukhaimane observed: "It is surprising that nearly every scholar who attempts to write about the ZCC of Engenas wants to deny the church its status as a Christian church. Such writers fill their own libraries and amuse their readers by concentrating on fairy tales, while ignoring concrete facts about the church" (Lukhaimane 1991, 237). Lukhaimane defended this church as an eyewitness to the church and as its member. Politically, the ZCC viewed itself as the leading African Christian church, as opposed to the Western church that claimed to be African, although it was discriminated against by white mainline and Pentecostal churches. In the $21^{\text {st }}$ century, in South Africa, white mainline and Pentecostal churches were losing members who joined the ZCC. Masilo Molobi maintained: "The question of dependency had been common among many of the AICs and their leaders had taken this seriously. The AICs inculturated Christianity in Africa in such a way that it had considerable consequences for African theology" (Molobi 2013, 59). The ZCC and other AICs were founded because of political reasons such as the fact that black people were not allowed to practise their customs and spiritual 
gifts. They were denied the opportunity to be trained as ministers, or they were trained but not given the opportunity to be ministers. The ZCC liberated itself in order to be an independent church that practised its spiritual faith without being offered an oppressive manual by dominant European policies and supervision. On the other hand, the black South African missionary and Pentecostal churches remained within the oppressive systems of European policies and supervision.

Black ministers within the missionary and Pentecostal churches were theologically trained to minister to the black townships in predominantly black churches, without being allowed to minister to the predominantly white churches and communities (Denis, Mlotshwa and Mukuka 1999, 41). The church, socio-economically and politically, favoured the white ministers with decent salaries while black ministers continued to be exploited and disempowered financially because of their colour and language. Within the ZCC circle, on matters of the healthy economics of its pastors, Lukhaimane states that the church was in a process of transforming church administration on the question of leadership and funds (Lukhaimane 1991, 239). Lukhaimane does not explain how the finances of ZCC pastors and other benefits of the church were distributed.

\section{FAITH AND REALITIES OF ZCC TO PROTESTANT AND PENTECOSTAL CHURCHES}

Bengt Sundkler and Christopher Steed provide the perception that Roman Catholic and Protestant churches have used the Western design of building hospitals as the healing facilities to service the sick people (Sundkler and Steed 2000, 674). Western medicine and antibiotics have been used at a cheaper price to alleviate the sickness and suffering of the black poor masses in Africa. The qualified medical doctors, sisters, nurses and medical assistants have traditionally been whites who ministered among the black Africans. Although these Western trained professionals have been helpful to the sick, for Africans, there has not been enough healing because Africans have always believed in African spiritual healing. Thinandavha Mashau states: "As much as the hegemony of Western biomedicine, as endorsed by missionaries in the past, can no longer serve as a norm in the area of healing, we can also use the African traditional healing methods and, or any other alternative presented to Africa without discernment" (Mashau 2016, 1). This has been influenced by the fact that the approaches of healing to African black people are not only physical, but collectively spiritual and physical. The Western traditional and Roman Catholic and Protestant way of healing is not complementary to the African approach of healing. Sundkler and Steed state: "Many Africans, and by no means only the less educated among them, felt that the Western medical approach was insufficient and limited for it had overlooked the role of the supernatural world" (Sundkler and Steed 2000, 677). The African protest against the Western medical approach did not advocate for the removal of the Western medical approach, but for white Westerners to include African medical and spiritual approach. In other words, the African spiritual world could have been acknowledged in essence of practice. Africans 
understand the AICs as African churches within the context of the spiritual hospital, as ancestors and God are at the heart of the African worldview. They believe that healing is associated with the spiritual world rooted in God, and their ancestors as the mediators. Healing by prophets has always been central in the African context. Lwandle affirms this: "The prophet claims that his power to diagnose the causes of diseases comes from the Holy Spirit, the healer regards his as coming from the ancestral spirits. The prophet would insist that therapy consists of exorcism of the threatening spirits which is an act representing the healing power of the Christian God" (Lwandle 1992, 86).

Mashau provides another perspective of healing which appeals to the African context: "Emphasis on the resurgence of the charisma of healing among African Pentecostals and the charismatic movement in the life of the African church placed great emphasis on prayer for healing, to a point where medical treatment in some churches was rejected" (Mashau 2016, 1). African Pentecostals, the charismatic movements and the AICs that rejected the Western medical treatment of the Africans, have been regarded as a great trick to mislead and kill the innocent African people. This can be viewed as a criminal act to deny the sick, innocent Africans to live under their human rights and dignity to life in Africa. Healing in the mainline churches has always been influenced by the Western approach accompanied with God's intervention, fasting and prayer for healing. Cephas Narh Omenyo (2006) argues that the African people have moved from the mainline churches to the African Pentecostal and charismatic movements in search of God's divine healing. These movements have become popular because of their emphasis on healing by faith in God, and the Bible as a central doctrine (Omenyo 2006, 237). In Africa, health is defined as the source for the wholeness of life within the botho (humanity) concept. It is within this context that the African spirituality and Christianity are collectively viewed as the African spiritual life.

This growing and popular faith of the ZCC church has continued to remain relevant to the African context within the urban and rural areas of South Africa. In an interview, one ZCC member lamented: "While church black members are Protestant during the day, in the evening they come to ZCC" (Mashabela 2016). This refers to black members of these mainline and Pentecostal churches who often visit the ZCC to receive healing and then revert to their churches. Maluleke calls for an evaluation of African missionary churches, African Pentecostal churches and AICs. He states: "It is, in fact, healthy for theologies to have critical relations. But such relations should not be based on the assumption of false differences. The difference between liberation theologies and AIC theologies is not, in my opinion, necessarily one of quality" (Maluleke 1996, 41). The context of this debate is that African theologies have always been in critical dialogue with other theologies in such a way that "may reveal a continuous rather than discontinuous relationship between African Pentecostals and black mission churches", which also includes the AICs (Maluleke 1994, 62). A more unique research study could be done within Africa on the African Protestant churches, African Pentecostal churches and AICs on matters of theologies and liturgy to enhance African Christianity for the benefit of the black Africans. These African churches need to create an African 
theological dialogue to redefine their theologies to be appropriated into our African context. African scholars, through theological education, could address the spiritual needs of the African community as a matter of urgency. Thus, African theologies could be valued by developing scholarships and research for the enhancement of the concept of botho (humanity) in Africa. This could create the united critical African church and united critical African community to shape the future of the critical African Christianity. African Christianity could continually develop on transformation because of contributions such as that of ZCC theology.

In 1997, an international conference on "African Initiatives in Christian Mission in Southern Africa" was organised by a collegiality of missionary churches, AICs, academics and practitioners, who were black and white, in the Department of Missiology at the University of South Africa (Cuthbertson, Pretorius and Robert 2003, viii-ix). The conference reviewed the injustices and distorted information written by white missionaries about the true identity of the AICs and also the historical literature on Christian missions in Africa. White missionaries operated and were mandated to work within the oppressive and unjust Western mission policies, which were controlled by the European imperialists. The conference needed to correct and find a solution to ensure that:

The contribution of the AICs to the growth and religion-cultural footedness of Christianity in Africa is of vital importance for the development of a relevant mission theology in Africa. It is increasingly evident that in terms of growth rates, indigenised evangelisation, missionary campaign, and ecclesiastic contextualisation, the AICs are not peripheral but belong to the mainstream of African Christianity. (Cuthbertson et al. 2003, viii)

It is within this context that an African Independent Church, such as the ZCC, has become part of the African Christianity that contributed to the growth of African theology within the context of historical ecclesiastic contextualisation. Thus, the ZCC belongs within the African Christianity movement as a stronghold of the healing aspect in an African cultural context. The ZCC, as the defining factor for the popular faith, precisely addresses the spiritual needs of the African people. South African black and white communities, even today, do not view the ZCC as a Christian church, due to its own spiritual Africanisation. However, ZCC members unapologetically view their church as an African Christian Church. African theological education, together with African theologians, will need to deconstruct the roots of white coloniality and oppression on African spirituality, and need to redress the fact that AICs are not regarded as Christianity. The reconstruction method could be used to evaluate AICs, mainline churches, Pentecostal churches and Christianity in order to become African Christianity that is relevant to the African community.

\section{CONCLUSION}

The ZCC continues to thrive as an AIC that keeps its mandate of being an African spiritual religion and culture in order to meet the needs of its African people. This is 
emphasised to embrace its own common good identity without being patronised and undermined by current religious, socio-economic and political structures of South Africa. The ZCC wants the ministry of liberation without exploitation, geared towards an African church that defines a society within the context of freedom; to live in an act of partnership with the African people. African theologians have always emphasised that blacks must live out the Gospel as Africans, as opposed to Europeans. African theologians must assist the ZCC and other AICs' untrained priests to be theologically trained. On the other hand, these AICs' theologies will assist academic African theology to be relevantly written by these untrained AIC priests who are experts in the field of AICs. African Protestant churches, African Pentecostal churches and higher theological education must acknowledge the contribution of the ZCC in order to heal and build the African community. Of course, higher African theological education must begin to critically engage these highlighted churches together with other AICs on African healing in a new, democratic South Africa. With regard to healing and faith in a cultural context, there is a need for Africanisation that listens to black indigenous knowledge and voices from an African perspective.

African spiritual healing methods, Pentecostal, charismatic, AIC and Western medical approach by mainline churches could be embraced as a key to healing for the African people. All African churches and governments should collectively be responsible and should support the African approach of healing in its wholeness in Africa. The African churches' and governments' financials should be prioritised for the ministry of healing and welfare work for the African people. There should be a strong emphasis on providing analytical and qualitative African hospitals and prayer for healing in African churches without limiting any of these approaches. Medical curricula for practitioners at universities and other institutions of medicine should emphasise the African context. African churches and governments should invest in medical scholarships to push the African medical agenda. African theologians, theological institutions, African churches and spiritual traditional doctors should establish African conferences on African health to provide programmes that will educate people who come to medical centres, churches and dingaka (spiritual doctors). Western institutions should provide financial support and ideas without dictating to the African spirituality, but should listen and learn how Africans approach their health system. All these African churches should embrace their diverse spirituality for the sake of the African well-being. This means all these African churches, as agents for change, are ready for spiritual renewal and development for liberation and transformation in Africa for African people. It is critically important to acknowledge that Christianity has found its origin in Africa, although it was distorted by the Western missionary movement. Thus, the ZCC and other AICs have contributed greatly to the growth of African Christianity, and no doubt the African spirituality is also campaigning and continuing to impact Christianity in Africa. 


\section{REFERENCES}

Anderson, A. 2003. "Healing in the Zion Christian Churches of Southern Africa: Daneel's Research in Zimbabwe compared with the South African Movement". In Frontiers of African Christianity: Essays in honour of Inus Daneel, edited by G. Cuthbertson, H. Pretorius and D. Robert. Pretoria: Unisa Press.

Anderson, A. H. 1999. "The Lekganyanes and Prophecy in the Zion Christian Church.” Journal of Religion in Africa, no. XXIX (3).

Cuthbertson, G., Pretorius, H., and Robert, D. (eds). 2003. Frontiers of African Christianity: Essays in honour of Inus Daneel. Pretoria: Unisa Press.

Denis, P., Mlotshwa, T., and Mukuka, G. (eds). 1999. The Casspir and the Cross: Voices of Black Clergy in the Natal Midlands. Pietermaritzburg: Cluster Publications.

Häselbarth, H. 1966. "The Zion Christian Church of Edward Lekganyane." In Our approach to the Independent Church Movement in South Africa: Lecturers of the first Missiological Course of the Missiological Institute at the Lutheran Theological College, Mapumulo from 30 September to 6 October 1965, edited by H. J. Becken. Natal: Missiological Institution, Mapumulo Lutheran College.

Kretzschmar, L. 1986. The voice of Black Theology in South Africa. Johannesburg: Ravan Press.

Lebeloane, L., and Madise, M. 2006. "The use of Different Types of Water in the Zion Christian Church." Studia Historiae Ecclesiasticae, no. XXXII (2).

Lukhaimane, E. K. 1991. "The St. Engenas Zion Christian Church.” In Afro-Christian Religion at the Grassroots in Southern Africa: African Studies, volume 19, edited by G. C. Oosthuizen and I. Hexham. Lewiston: The Edwin Mellen Press.

Lwandle, P. S. 1992. "Christology in the African Independent Churches." Dynamic African Theology Umphumulo’s Contribution. Durban: Pinetown Printers.

Maimela, S. S. 1985. "Salvation in African Traditional Religions.” Missionalia, no. 13.

Maluleke, T. S. 1994. "Book review of Tumelo by Allan Anderson.” Missionalia, no. 22 (1).

Maluleke, T. S. 1996. "Research Methods on AICs and other Grass-Root Communities." Journal of Black Theology in South Africa, no. 10 (1).

Maluleke, T. S. 2003. "Interpreting the Interpreters of AICs and other Grassroots Christian Communities in South Africa." In Frontiers of African Christianity: Essays in honour of Inus Daneel, edited by G. Cuthbertson, H. Pretorius and D. Robert. Pretoria: Unisa Press.

Mashabela, J. K. 2016. James Kenokeno Mashabela interviewed undisclosed members of the ZCC at Soweto.

Mashau, T. D. 2016. "Moving to Different Streams of Healing Praxis: A Reformed Missionary Approach of Healing in the African Context." Verbum et Ecclesia 37 (1): 1508.

Molobi, M. 2013. "The Historical Voices of the African Independent Churches: Towards New Development." Studia Historiae Ecclesiastica, no. 39. 
Moripe, S. 1996. "The Organisation and Management of The Zion Christian Church." PhD thesis. University of Durban-Westville.

Ngada, N. H. 2001. African Christian Witness: The Movement of the Spirit in African Indigenous Churches. Pietermaritzburg. Cluster Publication.

Omenyo, C. N. 2006. Pentecost outside Pentecostalism: A Study of the Development of Charismatic Renewal Churches in Ghana. Zoetermeer: Boekencentrum.

Poewe, K., and Hexham, I. 1989. Introduction \& Preface. In Afro-Christian Religion and Healing in Southern Africa. African Studies, volume 8, edited by G. C. Oosthuizen, S. D. Edwards, W. H. Wessels and I. Hexham. Lewiston: The Edwin Mellen Press.

Radebe, Z. 2008. "State Sovereignty and Alternative Community in Southern Africa: Exploring the Zion Christian Church as the Building Block for Deeper Notions of Regional Community." MA dissertation. Rhodes University.

Sundkler, B., and Steed, C. 2000. A History of the Church in Africa. United Kingdom: Cambridge University Press. 